\title{
Mapping beneficiaries of ecosystem services flows from Natura 2000 sites
}

\author{
Uta Schirpke $^{\mathrm{a}, \mathrm{b}, *, 1}$, Rocco Scolozzi ${ }^{\mathrm{a}, \mathrm{c}, 1}$, Claudio De Marco ${ }^{\mathrm{a}}$, Ulrike Tappeiner $^{\mathrm{a}, \mathrm{b}}$ \\ a Institute for Alpine Environment, EURAC research, Viale Druso 1, 39100 Bolzano, Italy \\ ${ }^{\mathrm{b}}$ Department of Ecology, University of Innsbruck, Sternwartestr. 15, 6020 Innsbruck, Austria \\ ${ }^{\text {c } C e n t r e ~ o f ~ M o l e c u l a r ~ a n d ~ E n v i r o n m e n t a l ~ B i o l o g y, ~ U n i v e r s i t y ~ o f ~ M i n h o, ~ B r a g a, ~ P o r t u g a l ~}$
}

\section{A R T I C L E I N F O}

Article history:

Received 11 January 2014

Received in revised form

26 May 2014

Accepted 18 June 2014

Available online 9 July 2014

Keywords:

Protected area

Ecosystem services

Conservation policy

Landscape planning

Natural resources

Spatial analysis

\begin{abstract}
A B S T R A C T
There is a growing need to integrate ecosystem services into management strategies of protected areas, and only a comprehensive ecosystem services assessment allows effective strategies for biodiversity conservation to be defined. Beneficiaries are largely disregarded or only mentioned in ecosystem services assessments related to protected areas. Thus, we propose indicators for identifying potential beneficiaries on the local and regional level, focusing on 16 relevant ecosystem services of Natura 2000 sites. For a case study in northern Italy, we used spatially-explicit modelling approaches to map and quantify the potential beneficiaries of multiple ecosystem services, including distance decay functions and basin catchment modelling. The resulting maps indicate that for provisioning and cultural services, the majority of the beneficiaries are located outside the protected area, whereas the beneficiaries of regulating services are mostly situated within or very close to it. The indicators and the beneficiary maps offer an important basis for an exhaustive assessment of ecosystem services flows from Natura 2000 sites and support the implementation of conservation policies by involving the local population and the community of users of protected areas.
\end{abstract}

\section{Introduction}

In recent decades, there has been an increasing interest in the concept of ecosystem services (ES) for decision-making and ecosystem management, to discuss the role of biodiversity on the global (Millennium Ecosystem Assessment (MEA), 2005; TEEB, 2010), the regional (Egoh et al., 2009; Eigenbrod et al., 2009), or the landscape scales (Bastian, 2013; Tscharntke et al., 2005). The ES valuation of protected areas, which aims to preserve natural environments and thus biodiversity, has mostly concentrated on national or natural parks (Martín-López et al., 2011; MartínezHarms and Gajardo, 2008). In Europe, conservation objectives of biodiversity are pursued through the establishment of the Natura 2000 network under the European Habitats Directive 92/43/EEC and the Birds Directive 79/409/EEC. Whereas conservation efforts in the past principally concentrated on preserving and restoring

\footnotetext{
* Corresponding author at: Institute for Alpine Environment, EURAC research, Viale Druso 1, 39100 Bolzano, Italy. Tel.: + 390471055 337; fax: + 390471055399 .

E-mail addresses: uta.schirpke@eurac.edu (U. Schirpke), scolozzi.rocco@gmail.com (R. Scolozzi), Claudio.DeMarco@eurac.edu (C. De Marco), ulrike.tappeiner@uibk.ac.at (U. Tappeiner).

${ }^{1}$ Joint first authors.
}

biodiversity, there is a growing need to integrate ES into management strategies, considering interactions between demand and supply of multiple ES and accounting for spatial and temporal scales (Anton et al., 2010; Naidoo et al., 2008). Based on the toolkit to assess the socio-economic benefits of Natura 2000 (Kettunen et al., 2009), initial ES assessments were carried out in different European regions (Bugalho, 2009; Cruz and Benedicto, 2009; Kazakova, 2009; Pabian and Bogdan, 2009; Tinch, 2009). Together with conserving biodiversity, the Natura 2000 network provides a wide range of provisioning, regulating and cultural ES (Brink et al., 2011). The socio-economic benefits of the Natura 2000 network have mostly been related to tourism and recreation, and their economic benefits are estimated to be between three and seven times their annual costs (Gantioler et al., 2010).

Especially in Europe, protected areas are placed within social contexts, where the interaction between natural processes and human activities has established social-ecological systems (Figueroa and Aronson, 2006). The ecological functioning of protected areas is affected by the landscape dynamics in the surrounding area (DeFries et al., 2007; Hansen and DeFries, 2007; Mcdonald et al., 2009; Wade et al., 2011) and by the attitude of users, such as visitors and local communities, or landowners (Allendorf et al., 2012; Jones et al., 2012; Vodouhê et al., 2010). Only a comprehensive ES analysis, including stakeholders and 
beneficiaries in their cultural, economic and policy context, allows effective management strategies to be defined (Anton et al., 2010), and in particular, beneficiaries outside the protected area play a crucial role in integrating the ES approach into conservation policies (Tallis et al., 2008). Although great progress has been made on mapping and quantifying ES in the last decade (Egoh et al., 2008, 2012; Raymond et al., 2009; Schägner et al., 2013; Troy and Wilson, 2006), to date, ES of Natura 2000 sites have only been assessed in terms of the potential of ES provision (Bastian, 2013; Kettunen et al., 2009), and most ES valuations consider ES beneficiaries only in qualitative terms or disregard them (Burkhard et al., 2012). Spatially explicit tools and methods that take into account the location and number of beneficiaries and their demands for ES, which might support the ES governance for protected areas in terms of both planning and public support, are still missing (Anton et al., 2010).

Therefore, this study focuses on the assessment of the beneficiaries related to the Natura 2000 network by:

- providing definitions of beneficiaries related to the Natura 2000 network;

- defining indicators for multiple ES to identify potential beneficiaries of Natura 2000 sites;

- using spatially explicit modelling approaches to map such indicators on the landscape scale; and

- mapping and quantifying potential beneficiaries for multiple ES for a case study in Italy.

\section{Definitions of beneficiaries related to the Natura 2000 network}

Natura 2000 sites and their beneficiaries have rarely been the focus of ES assessments (Bastian, 2013; Kettunen et al., 2009). Our literature review (Annex A) revealed that beneficiaries of ES from protected areas were largely disregarded (e.g., Armsworth et al., 2011; Bastian, 2013; Wade et al., 2011) or merely mentioned (e.g., Barton et al., 2009; Eigenbrod et al., 2009; Petrosillo et al., 2010; Rodríguez-Rodríguez and Martínez-Vega, 2012). Where identified (e.g. Juutinen et al., 2011; Palomo et al., 2013; Pietrzyk-Kaszyńska et al., 2012; van Riper et al., 2012), they were generally reported as interested categories such as private landowners, municipalities, local communities or visitors. In a few studies, beneficiaries were identified and specifically described, or in some cases also spatially recognised in the region and involved in the analysis or assessment (e.g., Brandon et al., 2005; Bernard et al., 2009; DeFries et al., 2010; Martín-López et al., 2011; Kari and Korhonen-Kurki, 2013; Mackenzie, 2012).
An ES beneficiary is defined as any group or individual that benefits from ecosystem goods and services, either through active or passive consumption of both, or through simple appreciation resulting from the awareness of these services (Nahlik et al., 2012). If there are no beneficiaries, the same ecosystem elements or processes cease to be ES (Boyd and Banzhaf, 2007). The ES benefits vary, depending on the type of service with its individual characteristics, in terms of the spatial extent and quality of the relationships between source areas and benefit areas (Bagstad et al., 2013; Costanza, 2008; Fisher et al., 2009). Each ES has a distinctive spatial range, related to specific ecological and economic processes, which can be local, regional/national or global (Hein et al., 2006). In the specific context of Natura 2000 sites, governance levels also distinguish between public and private sectors (Kettunen et al., 2009). The relationships between ES and beneficiaries can be described in terms of the intensity of the relationship, along a gradient of dependency and location (Table 1).

Among the several definitions of stakeholders in the literature, the most accepted is that of Freeman (Fassin, 2009): a stakeholder is "any group or individual who can affect or is affected by the achievement of the organisation's objective" (Freeman, 1984). This definition was adapted for ecosystem valuation into "any group or individual who can affect or is affected by the ecosystem's services" (Hein et al., 2006).

We propose a distinction between stakeholder and beneficiary in terms of the ability to influence ES provision (e.g., deciding policies) and the conditions of benefiting. The beneficiaries of ES from Natura 2000 sites can correspond to the stakeholders, which are subjects involved or interested in the management of the site, at different levels and through different perspectives (Hein et al., 2006). In general, each beneficiary should be considered as a stakeholder and involved in decision-making processes (Hein et al., 2006; Rastogi et al., 2010), but not vice versa: not all stakeholders are necessarily beneficiaries. Moreover, we can distinguish different degrees of dependency among the beneficiaries (Table 1). Fig. 1 schematises the relationship intensity in the ES in the protected area by concentric circles. This relationship is not permanent, even for the same subject and can vary in time, with changing variables and perspectives. For example, farmers strictly depend upon soil productivity (or primary productivity), whilst they are also indirect beneficiaries from the mitigation of natural extreme events (drought, floods); furthermore, farmers can enjoy recreational opportunities provided by the cultivated ecosystems (Swinton et al., 2007). Thus, a farmer can be simultaneously a dependent beneficiary, a direct and indirect beneficiary and a stakeholder, able to influence decisions in the area (A in Fig. 1) for different interests. In contrast, a public authority at the regional level (e.g., environmental authority) might be in charge of site management, but might not obtain any significant

Table 1

Intensity of relationship between beneficiaries and ES.

\begin{tabular}{|c|c|c|c|c|c|c|c|}
\hline $\begin{array}{l}\text { Beneficiary } \\
\text { type }\end{array}$ & $\begin{array}{l}\text { Substitution } \\
\text { costs }\end{array}$ & $\begin{array}{l}\text { Substitution } \\
\text { opportunities }\end{array}$ & $\begin{array}{l}\text { At } \\
\text { site }\end{array}$ & Dependency & Ecosystem services $^{\mathrm{a}}$ (examples) & $\begin{array}{l}\text { Benefit domain } \\
\text { (examples) }\end{array}$ & $\begin{array}{l}\text { Examples of } \\
\text { beneficiaries }\end{array}$ \\
\hline A & High & Low & Yes & Strong: totally depending on ES & Provisioning (cultivated crops) & $\begin{array}{l}\text { Agriculture } \\
\text { Forestry }\end{array}$ & Farmers \\
\hline B & High & Low & No & $\begin{array}{l}\text { Medium: depending on ES from } \\
\text { outside }\end{array}$ & $\begin{array}{l}\text { Regulation \& maintenance (water } \\
\text { regulation) }\end{array}$ & $\begin{array}{l}\text { Water retention } \\
\text { Flood mitigation }\end{array}$ & $\begin{array}{l}\text { Residents local } \\
\text { administration }\end{array}$ \\
\hline C & Low & High & Yes & $\begin{array}{l}\text { Low: depending on ES, but with } \\
\text { substitution opportunities }\end{array}$ & $\begin{array}{l}\text { Provisioning (fibres and timber) } \\
\text { cultural (experiential use of land) }\end{array}$ & Forestry Recreation & $\begin{array}{l}\text { Farmers } \\
\text { Residents }^{\mathrm{b}}\end{array}$ \\
\hline $\mathrm{D}$ & Low & High & No & $\begin{array}{l}\text { No dependency: easily } \\
\text { substitutable with other source } \\
\text { areas }\end{array}$ & Cultural (physical use of land) & Recreation & Visitors, hikers \\
\hline
\end{tabular}

\footnotetext{
ES definitions were derived from CICES V4.3.

b Including local tourism actors, e.g., hotel owners who offers bikes to recreants.
} 
benefit either direct or indirect (B in Fig. 1). Such a distinction between beneficiary groups helps to recognise the dependency of economic activity and well-being sources for local communities on Natura 2000 sites, and subsequently, to guide participatory approaches for their management and strategic planning: the group that is more dependent on ES and accordingly, more affected by losses or gains, should have the higher priority.

\section{Mapping potential beneficiaries}

\subsection{Indicators}

To identify the beneficiaries of protected areas in humandominated landscapes, we propose indicators for different ES (Table 2). The selected ES are relevant on the local or regional level, whereas ES with a global relevance such as genetic resources or carbon sequestration were excluded from the analysis. To

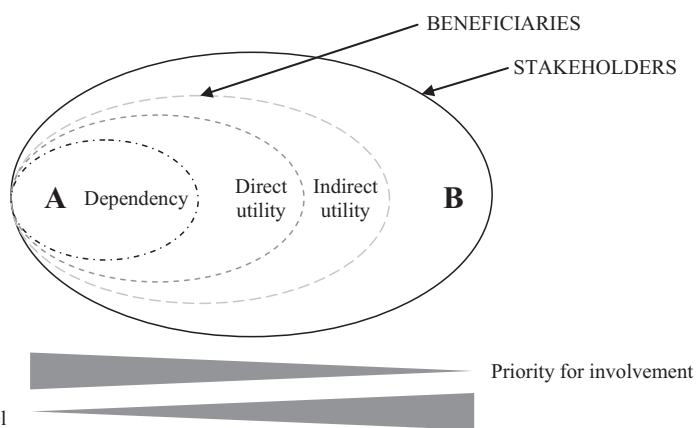

Fig. 1. Conceptual diagram of the categories of beneficiaries and stakeholders. identify the beneficiaries not only in potential terms, all indicators should be derived directly from local or regional data, e.g., the number of persons gathering mushrooms can be obtained from the number of licences issued by the municipality and the number of visitors to protected areas can be obtained from automated visitor counters. In many cases, however, direct data are not available and only potential beneficiaries can be estimated by using spatial information and available statistical data on the municipality level such as a population or agricultural census. In our case study, we mapped and quantified the potential beneficiaries of the Natura 2000 site 'Alto Garda Bresciano', based on GISbased modelling approaches as described in Section 3.2.2.

\subsection{Case study}

\subsubsection{Alto Garda Bresciano}

The Special Protection Area (SPA) Alto Garda Bresciano (IT2070402) is protected by the European Habitats Directive 92/43/EEC and the Birds Directive 79/409/EEC and is located in Lombardy (Italy) and covers an area of 21.526 ha. The SPA involves six municipalities with a total of 14,807 inhabitants (ISTAT, 2011a) with more than 1 million overnight stays per year (ISTAT, 2011b).

\subsubsection{Spatial mapping}

Based on spatial datasets and statistical information, potential beneficiaries were identified and mapped for different ES according to the indicators reported in Table 2. To exemplify the calculation of the indicators, spatial land cover information was derived from the CORINE land cover 2006 (CLC2006) seamless vector database consisting of 44 CLC-level-3 classes (EEA, 2013). Elevation was obtained from a digital elevation model (DEM) consisting of processed data from the ASTER Project (NASA, 2013). Local road networks were received from the geographical services of Lombardy, Veneto and Trentino. Statistical data

Table 2

Indicators for mapping potential beneficiaries.

\begin{tabular}{|c|c|c|c|c|c|}
\hline ES & & Indicator & $\begin{array}{l}\text { Beneficiary } \\
\text { type }\end{array}$ & Unit & Benefit area \\
\hline P1 & Agriculture & Farmer with crop cultivation & A & No farmers & $\begin{array}{l}\text { Agricultural land with annual or permanent } \\
\text { crops within protected area }\end{array}$ \\
\hline P2 & Forage, pasture & Farmer with livestock farming & A & No farmers & $\begin{array}{l}\text { Meadows and pastures within protected } \\
\text { area }\end{array}$ \\
\hline P3 & Game (wildlife) & Hunter and fisher & $\mathrm{C}$ & $\begin{array}{l}\text { No hunters, } \\
\text { No fishers }\end{array}$ & $\begin{array}{l}\text { Hunting- and fishing-ground within } \\
\text { protected area }+5 \mathrm{~km} \text { buffer }\end{array}$ \\
\hline P4 & Raw materials (timber and other wood fibre) & $\begin{array}{l}\text { Owner (public and private) of (exploitable) } \\
\text { forest }\end{array}$ & A & No owners & Forest within protected area \\
\hline P5 & Mushrooms and truffles & Persons gathering mushrooms and truffles & $\mathrm{C}$ & No persons & $\begin{array}{l}\text { Forest and other apposite land cover within } \\
\text { protected area }\end{array}$ \\
\hline P6 & Medical plants & Persons gathering medical plants & $\mathrm{C}$ & No persons & Selected land cover within protected area \\
\hline P7 & Fresh water & Residents within watershed & B & No residents & Watersheds intersecting the protected area \\
\hline $\mathrm{R} 1$ & Regulation of local air quality & Population benefiting from air purification & $\mathrm{B}$ & No residents & $\begin{array}{l}\text { Buffer in relationship to extent of filtering } \\
\text { land cover within the protected area }\end{array}$ \\
\hline $\mathrm{R} 2$ & Water purification & $\begin{array}{l}\text { Population benefiting from water } \\
\text { purification }\end{array}$ & $\mathrm{B}$ & No residents & Watersheds intersecting the protected area \\
\hline R3 & Erosion and landslide prevention & $\begin{array}{l}\text { Population benefiting from erosion and } \\
\text { landslide prevention }\end{array}$ & B & No residents & Watersheds intersecting the protected area \\
\hline R4 & Flood mitigation & Population benefiting from flood mitigation & B & No residents & Watersheds intersecting the protected area \\
\hline R5 & Pollination & $\begin{array}{l}\text { Farmer with crop cultivation close to } \\
\text { functional habitats for pollinators }\end{array}$ & B & No farmers & $\begin{array}{l}\text { Agricultural land within protected } \\
\text { area }+2.5 \mathrm{~km} \text { buffer }\end{array}$ \\
\hline R6 & Biological control & $\begin{array}{l}\text { Farmer with crop cultivation close to } \\
\text { functional habitats for beneficial species }\end{array}$ & $\mathrm{B}$ & No farmers & $\begin{array}{l}\text { Agricultural land within protected } \\
\text { area }+2.5 \mathrm{~km} \text { buffer }\end{array}$ \\
\hline $\mathrm{C} 1$ & Aesthetic value & Residents and tourists within visible area & $\mathrm{D}$ & No persons & Protected area $+10 \mathrm{~km}$ buffer \\
\hline $\mathrm{C} 2$ & $\begin{array}{l}\text { Recreational value (tourism, outdoor } \\
\text { activities) }\end{array}$ & Visitors for recreational activities & $\mathrm{D}$ & No visitors & $\begin{array}{l}\text { Urban areas with travel time }<90 \text { min from } \\
\text { protected area }\end{array}$ \\
\hline C3 & $\begin{array}{l}\text { Inspiration for arts and culture, spiritual and } \\
\text { educational values, sense of place }\end{array}$ & $\begin{array}{l}\text { People receiving inspiration, education, } \\
\text { identity }\end{array}$ & B & No residents & $\begin{array}{l}\text { Municipalities intersecting the protected } \\
\text { area }\end{array}$ \\
\hline
\end{tabular}


concerning population (ISTAT, 2011a), tourism (ISTAT, 2011b), and agriculture (ISTAT, 2010) on the municipality level were used to quantify potential beneficiaries. As these data refer to administrative units, they were transferred to the landscape scale by intersecting the CORINE dataset with the municipality borders (ISTAT, 2013). Subsequently, the population density was calculated for urban areas and the density of different farm types was obtained for selected agricultural land cover types (annual and/ or permanent crops, wine, woody agrarian cultivation, areas for forage production and grazing). Many ES refer to watersheds that were delimited based on the DEM and the existing river network (ISPRA, 2013), applying thresholds of 1,5 and $10 \mathrm{~km}^{2}$ for the minimum watershed size.

The GIS-based methods for estimating potential beneficiaries for each selected ES are hereafter described briefly. All calculations were automated by generating scripts in Python 2.7.2 (Python Software Foundation, NH, USA) and using standard routines provided with ArcGIS $10.1^{\text {TM }}$ (ESRI, Redlands, CA, USA).

- P1 Agriculture: the number of farm sites growing annual and permanent crops within the study was obtained from the farm density in the used agricultural areas after intersecting the land cover data with the Natura 2000 site.

- P2 Forage, pasture: the number of farmers using the territory of the Natura 2000 site for forage production and grazing were derived from the farm density with animal farming in the used areas within the Natura 2000 site.

- P3 Game (wildlife): to assess the number of potential hunters, habitats for reproduction and suitable hunting-grounds, which are ecologically connected, were considered within the Natura 2000 site and its surrounding area up to $5 \mathrm{~km}$. The fragmentation of elements such as main roads, urban areas, large rivers and very steep slopes $>80 \%$ was used to define the ecologically connected natural areas. Due to the lack of statistical data, a mean density of 0.5 hunters per $\mathrm{km}^{2}$ was assumed (considering local wildlife hunting plans, unpublished). For estimating the number of fishers, the minimum density of fishers was assumed, depending on the altitude, according to expert opinions and the following rules:

(a) Altitude $<600 \mathrm{~m}>$ river: four fishers/km; lake: 10 fishers $/ \mathrm{km}$

(b) Altitude 600-1200 m > river: two fishers/km; lake: five fishers $/ \mathrm{km}$

(c) Altitude $>1200 \mathrm{~m}$ : river $>$ one fishers $/ \mathrm{km}$; lake: three fishers $/ \mathrm{km}$

- P4 Raw materials (timber and other wood fibre): as no specific statistical data were available, the potential owners of exploitable forests were estimated based on the forest area within the Natura 2000 site and the population data of the intersecting municipalities.

- P5 Mushrooms and truffles: the potential beneficiaries were estimated based on the population of the intersecting municipalities with forest areas of the Natura 2000 site, which are suitable for mushrooming. Suitable areas were considered to be forests and open natural land with an elevation below $2000 \mathrm{~m}$ a.s.l. and a slope less than $80 \%$ (generally, areas in the region with this slope are cliffs).

- P6 Medical plants: the potential beneficiaries were estimated based on the population of the municipalities intersecting natural areas of the Natura 2000 site with a slope less than $80 \%$.

- P7 Fresh water: the population within the watersheds, intersecting the Natura 2000 sites, was derived by the population density for urban areas.

- R1 Regulation of local climate and air quality: to identify urban areas that benefit from air purification, filtering land-cover types were determined within the Natura 2000 site. After applying a buffer in proportion to the extension of the filtering area, the size of the benefiting population was obtained from the population density of the urban areas within the buffer.

- R2 Water purification: this ES only exists if ecosystems with a capacity of water purification occur between polluting elements and potentially impacted areas with beneficiaries. To identify the urban areas benefitting from water purification, it was tested whether the Natura 2000 site can contribute to the ES by analysing polluting elements and the relative position of impacted areas. Finally, the number of residents was obtained from the population density of the urban areas.

- R3 Erosion and landslide prevention: to test whether the Natura 2000 site has the ability to prevent or moderate landslides, forested areas, which have a positive influence on soil stability (Scrinzi et al., 2006), with a slope greater than $10^{\circ}$ (Trigila, 2007) were selected within the protected area and intersected with the watersheds. The whole municipality with all inhabitants was considered as a potential beneficiary.

- R4 Flood mitigation: for selecting urban areas that potentially benefit from flood mitigation of the Natura 2000 site, a riparian buffer of $100 \mathrm{~m}$ was used to identify the urban areas potentially prone to floods.

- R5 Pollination: farmers with cultivation that depends completely or partially on entomophilous pollination were determined by selecting the benefiting agricultural land within a buffer of $2.5 \mathrm{~km}$ from the potential habitats for pollinating insects included in the Natura 2000 site.

- $R 6$ Biological control: farmers with cultivation benefit from biological control through beneficial species and the number was calculated based on the agricultural areas within a buffer of $2.5 \mathrm{~km}$ from habitats for beneficial species within the protected area.

- C1 Aesthetic value: the Natura 2000 site mainly consists of natural and semi-natural habitats with great aesthetic value. Residents and tourists in urban areas with a view of the protected area are potential beneficiaries. Their number was determined by identifying the visible area up to $10 \mathrm{~km}$ from the protected area and by intersecting it with the urban areas. The number of residents was calculated based on the population density and the number of tourists was expressed as the number of available beds. Furthermore, all visitors to the protected area benefit from the aesthetic value of the site. Their number was estimated for $\mathrm{C} 2$.

- C2 Recreational value: potential visitors, residents and tourists were mapped based on the travelling time to the protected area. By attributing mean velocities for different road types of the road network, the travelling time was calculated starting from the Natura 2000 site and all urban areas within 90 min were selected. The number of residents was calculated based on the population density and the number of tourists was expressed as the number of available beds.

- C3 Inspiration for arts and culture, spiritual and educational values, sense of place: beneficiaries on the global level were not included. On the local level, the residents of all municipalities intersecting the Natura 2000 site were selected as potential beneficiaries.

\subsubsection{Potential beneficiaries maps}

For each ES, the potential beneficiaries were mapped (Fig. 2), and their total numbers are reported in Table 3. Regarding the different beneficiary types, the total number of beneficiaries increased with decreasing dependency (Table 4).

For the ES P1, P2, R5 and R6, the number of farmers was quantified based on the mapping of the agricultural area, but it was not possible to locate the farmers by their place of residence. 

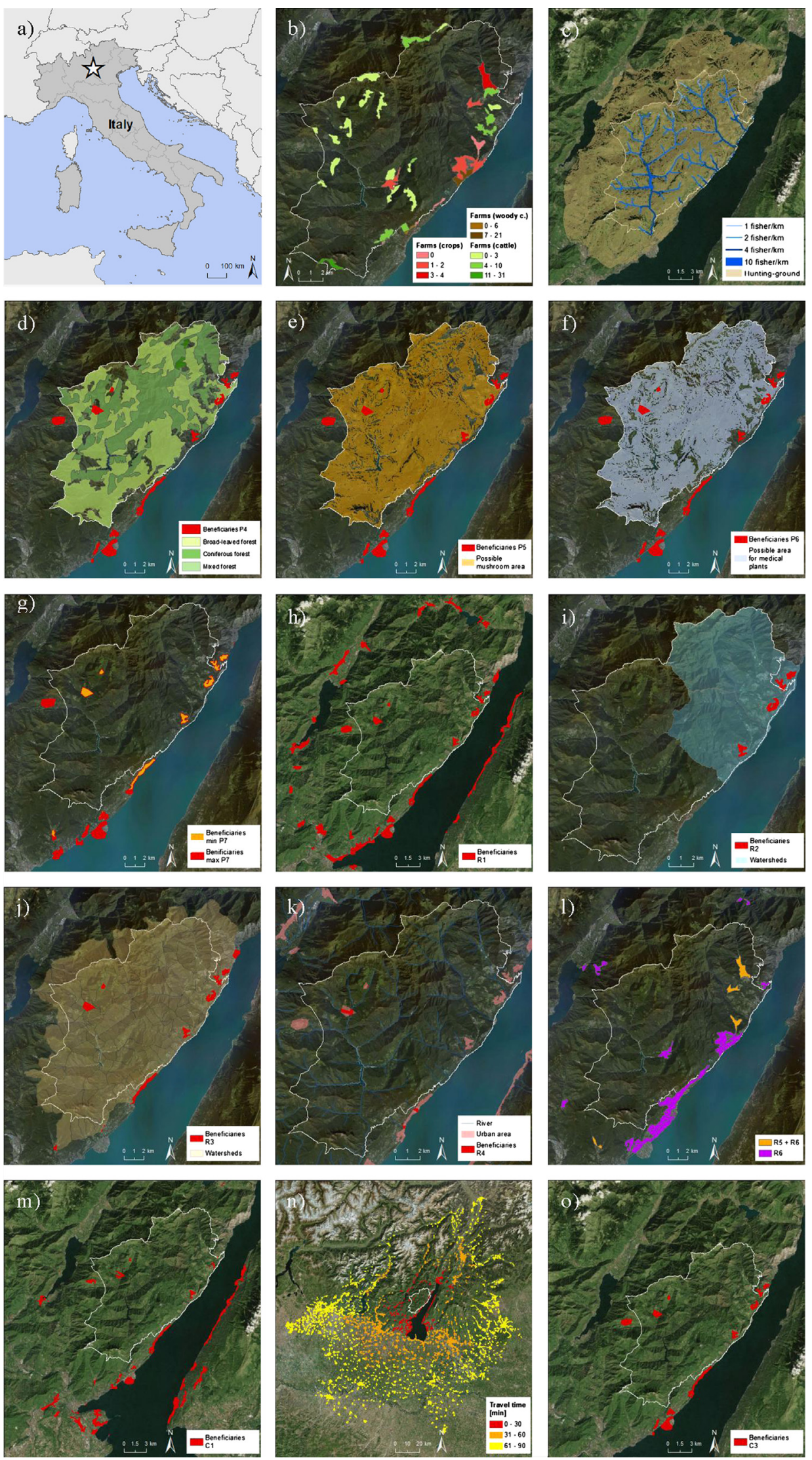

Fig. 2. (a) Location of study area (star). Maps of potential beneficiaries for (b) agriculture (P1) and forage, pasture (P2), (c) game (P3), (d) raw materials (P4), (e) mushrooms and truffles (P5), (f) medical plants (P6), (g) fresh water (P7), (h) regulation of local climate and air quality (R1), (i) water purification (R2), (j) erosion and landslide prevention (R3), (k) flood mitigation (R4), (l) pollination (R5) and biological control (R6), (m) aesthetic value (C1), (n) recreational value (C2), and (o) inspiration for arts and culture, spiritual and educational values, sense of place (C3). 
Table 3

Potential beneficiaries of the study area 'Alto Garda Bresciano'.

\begin{tabular}{|c|c|c|c|}
\hline ES & & Beneficiaries & \\
\hline P1 & Agriculture & $\begin{array}{l}10 \\
27\end{array}$ & $\begin{array}{l}\text { Farmers with annual and permanent crops } \\
\text { Farmers with olive groves }\end{array}$ \\
\hline P2 & Forage, pasture & $\begin{array}{l}62 \\
24\end{array}$ & $\begin{array}{l}\text { Farmers with cattle } \\
\text { Farmers with sheep/goat }\end{array}$ \\
\hline P3 & Game (wildlife) & $\begin{array}{l}387 \\
361\end{array}$ & $\begin{array}{l}\text { Hunters } \\
\text { Fishers (min) }\end{array}$ \\
\hline P4 & Raw materials (timber and other wood fibre) & $\begin{array}{l}14,807 \\
6\end{array}$ & $\begin{array}{l}\text { Residents } \\
\text { Municipalities }\end{array}$ \\
\hline $\begin{array}{l}\text { P5 } \\
\text { P6 }\end{array}$ & $\begin{array}{l}\text { Mushrooms and truffles } \\
\text { Medical plants }\end{array}$ & $\begin{array}{l}14,807 \\
14,807\end{array}$ & $\begin{array}{l}\text { Residents } \\
\text { Residents }\end{array}$ \\
\hline P7 & Fresh water & $\begin{array}{l}6272 \\
16,761\end{array}$ & $\begin{array}{l}\text { Residents (min) } \\
\text { Residents (max) }\end{array}$ \\
\hline $\begin{array}{l}\text { R1 } \\
\text { R2 } \\
\text { R3 } \\
\text { R4 } \\
\text { R5 }\end{array}$ & $\begin{array}{l}\text { Regulation of local climate and air quality } \\
\text { Water purification } \\
\text { Erosion and landslide prevention } \\
\text { Flood mitigation } \\
\text { Pollination }\end{array}$ & $\begin{array}{l}55,516 \\
3423 \\
7158 \\
803 \\
7\end{array}$ & $\begin{array}{l}\text { Residents } \\
\text { Residents } \\
\text { Residents } \\
\text { Residents } \\
\text { Farmers with annual and permanent crops }\end{array}$ \\
\hline R6 & Biological control & $\begin{array}{l}32 \\
180\end{array}$ & $\begin{array}{l}\text { Farmers with annual and permanent crops } \\
\text { Farmers with olive groves }\end{array}$ \\
\hline $\mathrm{C} 1$ & Aesthetic value & $\begin{array}{l}30,401 \\
51,779\end{array}$ & $\begin{array}{l}\text { Residents } \\
\text { Tourists }\end{array}$ \\
\hline $\mathrm{C} 2$ & Recreational value (tourism, outdoor activities) & $\begin{array}{l}5,830,153 \\
427,798\end{array}$ & $\begin{array}{l}\text { Residents } \\
\text { Tourists }\end{array}$ \\
\hline C3 & Inspiration for arts and culture, spiritual and educational values, sense of place & 14,807 & Residents \\
\hline
\end{tabular}

Table 4

Total potential beneficiaries of the study area 'Alto Garda Bresciano' aggregated by beneficiary type (see Tables 1 and 2 ).

\begin{tabular}{lll}
\hline Beneficiary type & No. beneficiaries & Percentage of total (\%) \\
\hline A & 14,930 & 0.2 \\
B & 88,198 & 1.4 \\
C & 30,159 & 0.5 \\
D & $6,340,131$ & 97.9 \\
Total & $6,473,418$ & \\
\hline
\end{tabular}

Active hunters or fishers were associated with the hunting-ground and lakes or rivers, respectively. For all other ES, the beneficiaries were quantified based on their place of residence or tourist accommodation facilities. Agriculture plays a minor role within the study area (12\% annual and permanent crops in the protected area). Nevertheless, $90 \%$ of the agricultural land that benefits from pollination (R5) is situated within the protected area, whereas 59\% of agricultural land outside the protected area benefits from biological control (R6). The number of potential beneficiaries of the ES P4-6 and C2 corresponds to all residents of the municipalities intersecting the beneficial area $(14,807$ residents), of which $18 \%$ are located within the protected area. The ES P7 and R2-4 were mapped on the watershed level and include only residents of the benefiting area (P7: 6272-16,761 residents, R2: 3423 residents, R3: 7158 residents, R4: 803 residents). Although for R 1 only $5 \%$ of the beneficiaries are within the protected area, for the other regulating services, up to $36 \%$ (R3) are located within the protected area or very close to it. The highest number of potential beneficiaries was mapped for the cultural services C1 and C2, and rose with increasing travelling time: 268,612 residents

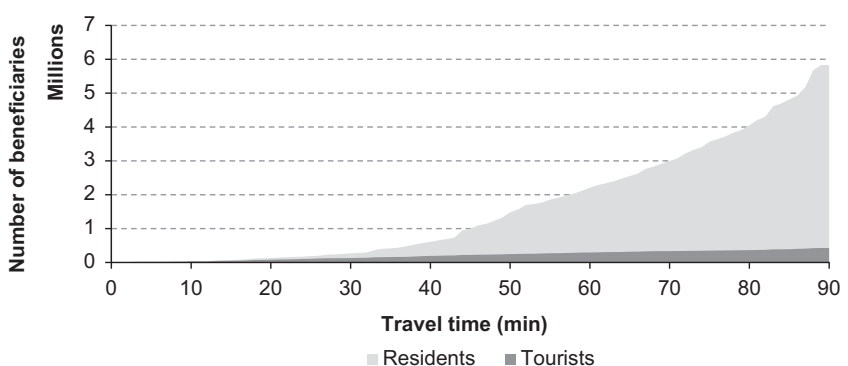

Fig. 3. Number of potential beneficiaries for recreation in relation to the travelling time.

and 129,571 tourists can reach the protected area with a maximum travelling time of $30 \mathrm{~min}$, and about 5.8 million residents and 0.4 million tourists are potential visitors if travelling up to 90 min (Fig. 3).

\section{Discussion and conclusion}

Integrating ES into conservation strategies requires a complete assessment of ES flows from protected areas, considering both the ES supply and demand, which varies with specific spatial and temporal conditions (Anton et al., 2010; Naidoo et al., 2008). The literature review, however, indicated that most studies disregarded or only mentioned the beneficiaries of ES from protected areas. Only in some cases were they also located and involved in the analysis, mainly by means of interviews or questionnaires (Martín-López et al., 2011; Vodouhê et al., 2010). The analysed studies confirm the importance of involving beneficiaries in ES assessments to identify ES flows, supported by an increasing demand in the surroundings of protected areas (Palomo et al., 
2013). Especially for the implementation of conservation actions, it is important to involve the local population and the community of users of protected areas located in a wider social-ecological system (DeFries et al., 2010). Whereas most studies have concentrated on ES supply (Burkhard et al., 2012), we focused on ES beneficiaries, proposing indicators to identify the beneficiaries of Natura 2000 sites on the local and regional level, and developing spatially-explicit modelling approaches to locate and estimate potential beneficiaries The various beneficiaries were related to the four categories of beneficiaries considering a dependency gradient and the distance from the site (Tables 1 and 2).

The application of these GIS-based models for a study site in Italy was based on CORINE land cover and national statistical datasets, because these datasets are generally available for most European countries, but finer land use/cover information and more detailed statistical data might produce more meaningful results. Using general rules for identifying potential beneficiaries allows the application to any protected area, although this might lead to an over- or underestimation of their number. For example, considering all residents of the interested municipalities for some ES (P4-6) might include people that are not beneficiaries because they do not own a forest or cannot access the area for gathering mushrooms or medical plants, but people might also come from the surrounding area, which were not included.

Methods such as interviews, questionnaires, conversations with people and participant observation have been applied in other studies (Bernard et al., 2009; Martín-López et al., 2011; Vodouhê et al., 2010), but are very time-consuming. With regard to the ES P1-2 and R5-6, the number of farmers was related to different farming types and represents the beneficiaries for that specific category, although the beneficiaries of provisioning services are in most cases not limited to the local or regional level. Goods and products can be consumed by international customers, affecting the local economy by an increasing or decreasing demand of certain products (Martín-López et al., 2011). In contrast, the beneficiaries of regulating services are mainly limited to the local and regional level (Fisher et al., 2009), and the maps indicate that beneficiaries of regulating services, with the exception of R1, are mainly located within or very close to the protected area. To identify these, it was tested whether the protected site has a positive influence on the provision of ES, but this was not intended to define the magnitude of influence, i.e., the assessment was limited to surface watersheds (P7, R2-4) or simple distance functions (R1 and R5-6). To quantify ES provision, complex ecological functions and processes should be considered and more sophisticated models should be applied.

With regard to the beneficiaries of cultural ES (C1 and C2), the potential beneficiaries do not represent the number of visitors, which can be obtained from automated visitor counters. The potential beneficiaries are mainly located outside the protected area and their number rises with increasing travelling time (Fig. 3), but environmental and socio-economic characteristics determine whether the protected area is capable of supporting a large number of persons without degradation of ecosystems and loss of recreational value (DeFries et al., 2010).

Although the spatially explicit modelling approaches to identify and quantify potential ES beneficiaries are based on general rules and approximations, they are easily applicable and can support a comprehensive assessment of ES flows from Natura 2000 sites, even at the regional scale. Furthermore, the scripts allow application to other study sites and calculations can be repeated rapidly for changed land-use information or updated statistical data, as well as for land-use scenarios. This methodological proposal, even though it has been shaped for European contexts, is appropriate to be applied to any protected area located within human-dominated landscapes.
Regarding the dependency and location of the beneficiaries, our results indicate that the number of beneficiaries increases when dependency decreases (Table 4); specifically, the local type A beneficiaries, are only a small proportion of the total number of the potential beneficiaries $(0.2 \%$ of the total, and $11.2 \%$ of the $A, B$, $C$ categories). These results can improve management and planning aspects of Natura 2000 sites or other protected areas. The local communities are considered for their capacity to manage reserves and support biodiversity through environmentally friendly economic activities within and around protected areas, and a solid understanding of the social context and the appropriate mechanisms for participation are claimed for natural reserve establishment and management (Brandon et al., 2005). However, management and planning generally consider only local beneficiaries and disregard those relatively distant to the site, but which have low opportunities or high costs for substitution (c.f. references in Annex A). DeFries et al. (2010) proposed the concept of a "zone of interaction" around protected areas that encompasses hydrological, ecological, and socioeconomic interactions between a protected area and the surrounding landscape. The designation of such zones of interaction improves the understanding of which activities (e.g., collection of forest products, grazing, road construction, tourism development) and which locations within the zone of interaction are most crucial to conservation goals and might enable improved land-use planning around protected areas in human-dominated landscapes. Our results provide a spatially-explicit quantification corresponding to site characteristics, such as distinctive ES and related beneficiaries, focusing on local and regional levels of both governance and ecological processes. Thanks to the distinction in different beneficiary groups, which were associated with a particular ES, especially the number of potential beneficiaries constitutes a valuable argument against the fact that Natura 2000 sites, as common for other protected areas, are often scrutinised as costing too much and delivering too little. This is important for an improved communication with, and involvement of, local communities, a better understanding and presentation of the benefits of protected areas, and especially for the communication with a wider audience (Brandon et al., 2005). Thus, the mapping of beneficiaries claims a wider public support.

\section{Acknowledgements}

This work was supported by the European Union through the LIFE+ Project 'Making Good Natura' (LIFE11 ENV/IT/000168). We thank the reviewers for their helpful input.

\section{Annex A. Literature review}

The literature review included studies related to terrestrial protected areas. The selection of relevant peer-reviewed paper was performed using different search engines (Google Scholar, ScienceDirect) and several combinations of the following key words: "ecosystem services", "protected area", "biodiversity conservation" or "park", looking at the period from 1997 to May 2013. The selection resulted in 147 articles, of which only 60 specifically considered protected areas and terrestrial ecosystems. For this subset of articles, we analysed how beneficiaries were involved, using the following categories:

1. Ignored: no reference was made to beneficiaries of protected areas, only allusions to the general community of beneficiaries (e.g., the world human population or national population).

2. Mentioned: beneficiaries were simply mentioned as group/ community or as users of protected areas. 
Table A1

Studies considering beneficiaries.

\begin{tabular}{|c|c|c|c|c|}
\hline How considered & Count & EU & Non-EU & Nd \\
\hline Ignored & 19 & $\mathrm{a}, \mathrm{b}, \mathrm{c}, \mathrm{d}, \mathrm{e}, \mathrm{f}, \mathrm{g}$ & $\mathrm{h}, \mathrm{i}, \mathrm{j}, \mathrm{k}, \mathrm{l}, \mathrm{m}, \mathrm{n}, \mathrm{o}, \mathrm{p}, \mathrm{q}$ & $\mathrm{r}, \mathrm{s}$ \\
\hline Mentioned & 16 & $\mathrm{t}, \mathrm{u}, \mathrm{v}, \mathrm{w}, \mathrm{x}$ & $\mathrm{y}, \mathrm{z}, \mathrm{aa}, \mathrm{ab}, \mathrm{ac}, \mathrm{ad}, \mathrm{ae}, \mathrm{af}$ & ag, ah, ai \\
\hline Identified & 10 & aj, ak, al, am, an, ao & ap, aq, ar, as & \\
\hline Quantified & 15 & at, au, av, aw & ax, ay, az, ba, bb, bc, bd, be, bf, bg, bh & \\
\hline
\end{tabular}

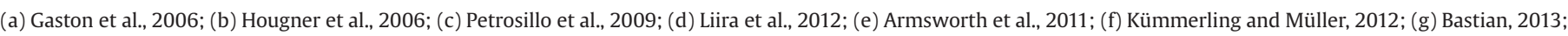

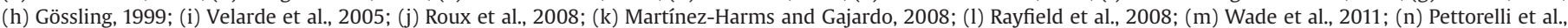

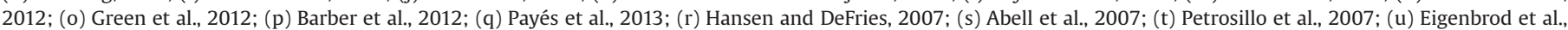

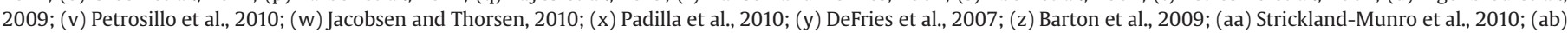

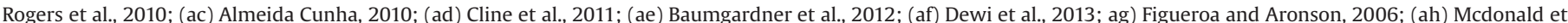

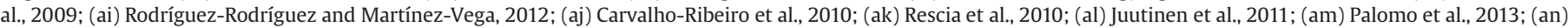

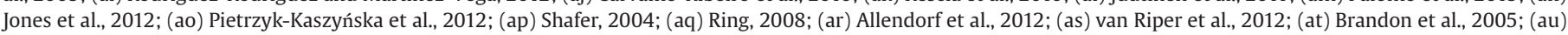

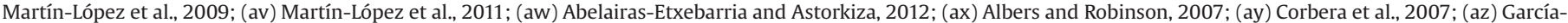

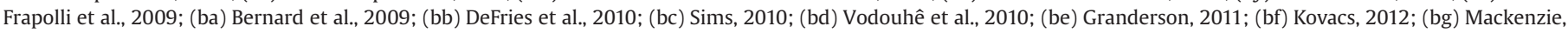
2012; (bh) Kari and Korhonen-Kurki, 2013.

3. Identified: beneficiaries were distinguished or described by specific information.

4. Quantified: beneficiaries were identified and quantified or at least described by some quantitative attributes (including geographical characterisation).

Furthermore, since the Natura 2000 network is an European instrument, we distinguished European from non-European studies. The results of the literature review are summarised in Table A1.

\section{References}

Allendorf, T.D., Aung, M., Songer, M., 2012. Using residents' perceptions to improve park-people relationships in Chatthin Wildlife Sanctuary, Myanmar. J. Environ. Manag. 99, 36-43.

Anton, C., Young, J., Harrison, P., Musche, M., Bela, G., Feld, C., Harrington, R., Haslett, J., Pataki, G., Rounsevell, M., Skourtos, M., Sousa, J., Sykes, M., Tinch, R., Vandewalle M., Watt, A., Settele, J., 2010. Research needs for incorporating the ecosystem service approach into EU biodiversity conservation policy. Biodivers. Conserv. 19, 2979-2994.

Armsworth, P.R., Cantú-Salazar, L., Parnell, M., Davies, Z.G., Stoneman, R., 2011 Management costs for small protected areas and economies of scale in habitat conservation. Biol. Conserv, 144, 423-429.

Bagstad, K.J., Johnson, G.W., Voigt, B., Villa, F., 2013. Spatial dynamics of ecosystem service flows: a comprehensive approach to quantifying actual services. Ecosyst. Serv. 4, 117-125.

Barton, D.N., Faith, D.P., Rusch, G.M., Acevedo, H., Paniagua, L., Castro, M., 2009 Environmental service payments: evaluating biodiversity conservation tradeoffs and cost-efficiency in the Osa Conservation Area. Costa Rica 90, 901-911.

Bastian, O., 2013. The role of biodiversity in supporting ecosystem services in Natura 2000 sites. Ecol. Indic. 24, 12-22.

Bernard, F., de Groot, R.S., Campos, J.J., 2009. Valuation of tropical forest services and mechanisms to finance their conservation and sustainable use: a case study of Tapantí National Park, Costa Rica. For. Policy Econ. 11, 174-183.

Boyd, J., Banzhaf, S., 2007. What are ecosystem services? The need for standardized environmental accounting units. Ecol. Econ. 63, 616-626.

Brandon, K., Gorenflo, L.J., Rodrigues, A.S.L., Waller, R.W., 2005. Reconciling biodiversity conservation, people, protected areas, and agricultural suitability in Mexico. World Dev. 33, 1403-1418.

Brink, P., Bassi, S., Badura, T., Gantioler, S., Kettumen, M., Mazza, L., Hart, K., Rayment, M., Pieterse, M., Daly, E., Gerdes, H., Lago, M., Lang, S., Markandya, A., Nunes, P., Ding, H., Tinch, R., Dickie, I., 2011. Estimating the Overall Economic Value of the Benefits provided by the Natura 2000 Network, Final Report to the European Commission, DG Environment on Contract ENV.B.2/SER/2008/0038. Institute for European Environmental Policy/GHK/Ecologic, Brussels p. 2011.

Bugalho, M., 2009. Assessing socio-economic benefits of Natura 2000 - a case study on the ecosystem service provided by the Natural Park of Vale do Guadiana (Portugal). Output of the Project Financing Natura 2000: Cost Estimate and Benefits of Natura 2000 (Contract no.: 070307/2007/484403/MAR/B2). 20 pp.

Burkhard, B., Kroll, F., Nedkov, S., Müller, F., 2012. Mapping ecosystem service supply, demand and budgets. Ecol. Indic. 21, 17-29.

Costanza, R., 2008. Ecosystem services: multiple classification systems are needed. Biol. Conserv. 21, 17-29.

Cruz, A., Benedicto, J., 2009. Assessing socio-economic benefits of Natura 2000 - a case study on the ecosystem service provided by SPA PICO DA VARA/RIBEIRA DO
GUILHERME. Output of the project Financing Natura 2000: Cost Estimate and Benefits of Natura 2000 (Contract no.: 070307/2007/484403/MAR/B2). 43 pp.

DeFries, R., Hansen, A., Turner, B., Reid, R., Liu, J., 2007. Land use change around protected areas: management to balance human needs and ecological function. Ecol. Appl. 17, 1031-1038.

DeFries, R., Karanth, K.K., Pareeth, S., 2010. Interactions between protected areas and their surroundings in human-dominated tropical landscapes. Biol. Conserv. $143,2870-2880$

EEA, 2013. Corine Land Cover 2006 (CLC2006) Seamless Vector Database - Version 16 (04/2012). Available at 〈http://www.eea.europa.eu/data-and-maps/data/ clc-2006-vector-data-version-2 $\rangle$ (accessed 23.03.13.).

Egoh, B., Drakou, E.G., Dunbar, M.B., Maes, J., Willemen, L., 2012. Indicators for mapping ecosystem services: a review. Report EUR, 25456.

Egoh, B., Reyers, B., Rouget, M., Bode, M., Richardson, D., 2009. Spatial congruence between biodiversity and ecosystem services in South Africa. Biol. Conserv. 142, 553-562.

Egoh, B., Reyers, B., Rouget, M., Richardson, D.M., Le Maitre, D.C., van Jaarsveld, A.S., 2008. Mapping ecosystem services for planning and management. Agric., Ecosyst. Environ. 127, 135-140.

Eigenbrod, F., Anderson, B.J., Armsworth, P.R., Heinemeyer, A., Jackson, S.F., Parnell, M., Thomas, C.D., Gaston, K.J., 2009. Ecosystem service benefits of contrasting conservation strategies in a human-dominated region. Proc. R. Soc. B: Biol. Sci. 276, 2903-2911.

Fassin, Y., 2009. The stakeholder model refined. J. Bus. Eth. 84, 113-135.

Figueroa, E., Aronson, J., 2006. New linkages for protected areas: making them worth conserving and restoring. J. Nat. Conserv. 14, 225-232.

Fisher, B., Turner, R.K., Morling, P., 2009. Defining and classifying ecosystem services for decision making. Ecol. Econ. 68, 643-653.

Freeman, R.E., 1984. Strategic Management: A Stakeholder Approach. Pitman, Boston.

Gantioler, S., Bassi, S, Kettumen, M., McConville, A, Brink, P. Rayment, M., Landgrebe, R., Gerdes, H., 2010. Costs and Socio-Economic Benefits associated with the Natura 2000 Network, Final report to the European Commission, DG Environment on Contract ENV.B.2/SER/2008/0038. Institute for European Environmental Policy/GHK/Ecologic, Brussels.

Hansen, A.J., DeFries, R., 2007. Ecological mechanisms linking protected areas to surrounding lands. Ecol. Appl. 17, 974-988.

Hein, L., van Koppen, K., de Groot, R.S., van Ierland, E.C., 2006. Spatial scales, stakeholders and the valuation of ecosystem services. Ecol. Econ. 57, 209-228.

ISPRA, 2013. River network for Italy. Available at $\langle$ http://www.sinanet.isprambiente. it) (accessed 11.04.13.).

ISTAT, 2010. Datawarehouse Censimento agricoltura. Available at $\langle$ http://www.istat. it (accessed 04.04.13.).

ISTAT, 2011a. Datawarehouse Censimento popolazione. Available at $\langle$ http://www. istat.it> (accessed 05.04.13.).

ISTAT, 2011b. Datawarehouse Servizi/Turismo. Available at 〈http://www.istat.it〉 (accessed 03.04.13.)

ISTAT, 2013. Spatial datasets with municipality borders available at $\langle$ http://www. istat.it/it/archivio/44523 (accessed 05.04.13.).

Jones, N., Clark, J., Panteli, M., Proikaki, M., Dimitrakopoulos, P., 2012. Local social capital and the acceptance of protected area policies: an empirical study of two Ramsar river delta ecosystems in northern Greece. J. Environ. Manag. 96, 55-63.

Juutinen, A., Mitani, Y., Mäntymaa, E., Shoji, Y., Siikamäki, P., Svento, R., 2011. Combining ecological and recreational aspects in national park management: a choice experiment application. Ecol. Econ. 70, 1231-1239.

Kari, S., Korhonen-Kurki, K., 2013. Framing local outcomes of biodiversity conservation through ecosystem services: a case study from Ranomafana, Madagascar. Ecosyst. Serv. 3, e32-e39.

Kazakova, Y., 2009. Assessing socio-economic benefits of Natura 2000 - a case study on the ecosystem services provided by Oaș-Gutâi Plateau and Ignis site, Maramures, Romania. Output of the Project Financing Natura 2000: Cost 
Estimate and Benefits of Natura 2000 (Contract no: 070307/2007/484403/ MAR/B2). 22 pp. + Annexes.

Kettunen, M., Ten Brink, P., Bassi, S., Gantioler, S., 2009. Assessing Socio-economic Benefits of Natura 2000 - A Toolkit for Practitioners (September 2009 Edition), Output of the European Commission project Financing Natura 2000: Cost Estimate and Benefits of Natura 2000 (Contract no: 070307/2007/484403/ MAR/B2). Institute for European Environmental Policy (IEEP), Brussels, Belgium p. 191 ( + Annexes).

Mackenzie, C.A., 2012. Accruing benefit or loss from a protected area: location matters. Ecol. Econ. 76, 119-129.

Martínez-Harms, M.J., Gajardo, R., 2008. Ecosystem value in the Western Patagonia protected areas. J. Nat. Conserv. 16, 72-87.

Martín-López, B., García-Llorente, M., Palomo, I., Montes, C., 2011. The conservation against development paradigm in protected areas: valuation of ecosystem services in the Doñana social-ecological system (southwestern Spain). Ecol. Econ. 70, 1481-1491.

Mcdonald, R.I., Forman, R.T.T., Kareiva, P., Neugarten, R., Salzer, D., Fisher, J., 2009. Urban effects, distance, and protected areas in an urbanizing world. Landsc. Urban Plan. 93, 63-75.

Millennium Ecosystem Assessment (MEA), 2005. Ecosystems and Human Wellbeing: Synthesis. Island Press, Washington, D.C..

Nahlik, A.M., Kentula, M.E., Fennessy, M.S., Landers, D.H., 2012. Where is the consensus? A proposed foundation for moving ecosystem service concepts into practice. Ecol. Econ. 77, 27-35.

Naidoo, R., Balmford, A., Costanza, R., Fisher, B., Green, R.E., Lehner, B., Malcolm, T., Ricketts, T.H., 2008. Global mapping of ecosystem services and conservation priorities. Proc. Natl. Acad. Sci. 105, 9495-9500.

NASA, 2013. ASTER L1B. Land Processes Distributed Active Archive Center (LP DAAC), USGS/Earth Resources Observation and Science (EROS) Center, Sioux Falls, South Dakota. Available at 〈http://gdem.ersdac.jspacesystems.or.jp/> (accessed 26.03.13.).

Pabian, O., Bogdan, J., 2009. Assessing socio-economic benefits of Natura 2000 - a case study on the ecosystem service provided by Białowieża Forest. Output of the Project Financing Natura 2000: Cost Estimate and Benefits of Natura 2000 (Contract no.: 070307/2007/484403/MAR/B2). 69 pp.

Palomo, I., Martín-López, B., Potschin, M., Haines-Young, R., Montes, C., 2013. National Parks, buffer zones and surrounding lands: mapping ecosystem service flows. Ecosyst. Serv. 4, 104-116.

Petrosillo, I., Semeraro, T., Zurlini, G., 2010. Detecting the 'conservation effect'on the maintenance of natural capital flow in different natural parks. Ecol. Econ. 69, $1115-1123$.

Pietrzyk-Kaszyńska, A., Cent, J., Grodzińska-Jurczak, M., Szymańska, M., 2012. Factors influencing perception of protected areas-the case of Natura 2000 in Polish Carpathian communities. J. Nat. Conserv. 20, 284-292.

Rastogi, A., Badola, R., Hussain, S.A., Hickey, G.M., 2010. Assessing the utility of stakeholder analysis to Protected Areas management: the case of Corbett National Park, India. Biol. Conserv. 143, 2956-2964.

Raymond, C., Bryan, B., MacDonald, D., Cast, A., Strathearn, S., Grandgirard, A., Kalivas, T., 2009. Mapping community values for natural capital and ecosystem services. Ecol. Econ. 68, 1301-1315.

Rodríguez-Rodríguez, D., Martínez-Vega, J., 2012. Proposal of a system for the integrated and comparative assessment of protected areas. Ecol. Indic. 23, $566-572$.

Schägner, J.P., Brander, L., Maes, J., Hartje, V., 2013. Mapping ecosystem services' values: current practice and future prospects. Ecosyst. Serv. 4, 33-46.

Scrinzi, G., Gregori, E., Giannetti, F., Galvagni, D., Zorn, G., Colle, G., Andrenelli, M., 2006. Un modello di valutazione della funzionalità protettiva del bosco per la pianificazione forestale: la componente stabilità dei versanti rispetto ai fenomeni franosi superficiali. Forest@ 3, 98-155.

Swinton, S.M., Lupi, F., Robertson, G.P., Hamilton, S.K., 2007. Ecosystem services and agriculture: cultivating agricultural ecosystems for diverse benefits. Ecol. Econ. $64,245-252$.

Tallis, H., Kareiva, P., Marvier, M., Chang, A., 2008. An ecosystem services framework to support both practical conservation and economic development. Proc. Natl. Acad. Sci. 105, 9457-9464.

TEEB, 2010. In: Kumar, Pushpam (Ed.), The Economics of Ecosystems and Biodiversity Ecological and Economic Foundations. Earthscan, London and Washington.

Tinch, R., 2009. Assessing Socio-economic benefits of Natura 2000 - a case study on the ecosystem service provided by the SUSTAINABLE CATCHMENT MANAGEMENT PROGRAMME. Output of the Project Financing Natura 2000: Cost Estimate and Benefits of Natura 2000 (Contract no.: 070307/2007/484403/ MAR/B2). 28 pp. + Annexes.

Rapporto sulle frane in Italia. In: Trigila, A. (Ed.), Il Progetto IFFI - Metodologia, Risultati e Rapporti Regionali. APAP, Roma, p. 681 (in Italian).

Troy, A., Wilson, M.A., 2006. Mapping ecosystem services: practical challenges and opportunities in linking GIS and value transfer. Ecol. Econ. 60, 435-449.

Tscharntke, T., Klein, A.M., Kruess, A., Steffan-Dewenter, I., Thies, C., 2005. Landscape perspectives on agricultural intensification and biodiversity - ecosystem service management. Ecol. Lett. 8, 857-874.

van Riper, C.J., Kyle, G.T., Sutton, S.G., Barnes, M., Sherrouse, B.C., 2012. Mapping outdoor recreationists' perceived social values for ecosystem services at Hinchinbrook Island National Park, Australia. Appl. Geogr. 35, 164-173.

Vodouhê, F.G., Coulibaly, O., Adégbidi, A., Sinsin, B., 2010. Community perception of biodiversity conservation within protected areas in Benin. For. Policy Econ. 12, 505-512.
Wade, A.A., Theobald, D.M., Laituri, M.J., 2011. A multi-scale assessment of local and contextual threats to existing and potential US protected areas. Landsc. Urban Plan. 101, 215-227.

\section{References in Annex A}

Abelairas-Etxebarria, P., Astorkiza, I., 2012. Farmland prices and land-use changes in periurban protected natural areas. Land Use Policy 29, 674-683.

Abell, R., Allan, J.D., Lehner, B., 2007. Unlocking the potential of protected areas for freshwaters. Biol. Conserv. 134, 48-63.

Albers, H.J., Robinson, E.J.Z., 2007. Spatial-temporal aspects of cost-benefit analysis for park management: an example from Khao Yai National Park, Thailand. J. For. Econ. 13, 129-150.

Allendorf, T.D., Aung, M., Songer, M., 2012. Using residents' perceptions to improve park-people relationships in Chatthin Wildlife Sanctuary, Myanmar. J. Environ. Manag. 99, 36-43.

Almeida Cunha, A., 2010. Negative effects of tourism in a Brazilian Atlantic forest National Park. J. Nat. Conserv. 18, 291-295.

Armsworth, P.R., Cantú-Salazar, L., Parnell, M., Davies, Z.G., Stoneman, R., 2011 Management costs for small protected areas and economies of scale in habitat conservation. Biol. Conserv. 144, 423-429.

Barber, C.P., Cochrane, M.A., Souza Jr., C., Veríssimo, A., 2012. Dynamic performance assessment of protected areas. Biol. Conserv. 149, 6-14.

Barton, D.N., Faith, D.P., Rusch, G.M., Acevedo, H., Paniagua, L., Castro, M., 2009. Environmental service payments: evaluating biodiversity conservation tradeoffs and cost-efficiency in the Osa Conservation Area. Costa Rica, J. Environ. Manag. 90, 901-911.

Bastian, O., 2013. The role of biodiversity in supporting ecosystem services in Natura 2000 sites. Ecol. Indic. 24, 12-22.

Baumgardner, D., Varela, S., Escobedo, F.J., Chacalo, A., Ochoa, C., 2012. The role of a peri-urban forest on air quality improvement in the Mexico City megalopolis. Environ. Pollut. 163, 174-183.

Bernard, F., de Groot, R.S., Campos, J.J., 2009. Valuation of tropical forest services and mechanisms to finance their conservation and sustainable use: a case study of Tapantí National Park, Costa Rica. For. Policy Econ. 11, 174-183.

Brandon, K., Gorenflo, L.J., Rodrigues, A.S.L., Waller, R.W., 2005. Reconciling biodiversity conservation, people, protected areas, and agricultural suitability in Mexico. World Dev. 33, 1403-1418.

Carvalho-Ribeiro, Lovett, O'Riordan, 2010. Multifunctional forest management in Northern Portugal: moving from scenarios to governance for sustainable development. Land Use Policy 27, 1111-1122.

Cline, S.A., Weiler, S., Aydin, 2011. The value of a name: estimating the economic impact of public land designation. Soc. Sci. J. 48, 681-692.

Corbera, E., Kosoy, N., Martínez Tuna, M., 2007. Equity implications of marketing ecosystem services in protected areas and rural communities: case studies from Meso-America. Glob. Environ. Change 17, 365-380.

DeFries, R., Hansen, A., Turner, B., Reid, R., Liu, J., 2007. Land use change around protected areas: management to balance human needs and ecological function. Ecol. Appl. 17, 1031-1038.

DeFries, R., Karanth, K.K., Pareeth, S., 2010. Interactions between protected areas and their surroundings in human-dominated tropical landscapes. Biol. Conserv. 143, 2870-2880.

Dewi, S., van Noordwijk, M., Ekadinata, A., Pfund, J.L., 2013. Protected areas within multifunctional landscapes: squeezing out intermediate land use intensities in the tropics? Land Use Policy 30, 38-56.

Eigenbrod, F., Anderson, B.J., Armsworth, P.R., Heinemeyer, A., Jackson, S.F., Parnell, M. Thomas, C.D., Gaston, K.J., 2009. Ecosystem service benefits of contrasting conservation strategies in a human-dominated region. Proc. Royal Soc. B: Biol Sci. 276, 2903-2911.

Figueroa, Aronson, 2006. New linkages for protected areas: making them worth conserving and restoring. J. Nat. Conserv. 14, 225-232.

García-Frapolli, E., Ramos-Fernández, G., Galicia, E., Serrano, A., 2009. The complex reality of biodiversity conservation through Natural Protected Area policy: three cases from the Yucatan Peninsula, Mexico. Land Use Policy 26, 715-722.

Gaston, K.J., Charman, K., Jackson, S.F., Armsworth, P.R., Bonn, A., Briers, R.A. Callaghan, C.S.Q., Catchpole, R., Hopkins, J., Kunin, W.E., Latham, J., Opdam, P., Stoneman, R., Stroud, D.A., Tratt, R., 2006. The ecological effectiveness of protected areas: the United Kingdom. Biol. Conserv. 132, 76-87.

Gössling, S., 1999. Ecotourism: a means to safeguard biodiversity and ecosystem functions? Ecol. Econ. 29, 303-320.

Granderson, A.A., 2011. Enabling multi-faceted measures of success for protected area management in Trinidad and Tobago. Eval. Program Plan. 34, 185-195.

Green, J.M.H., Burgess, N.D., Green, R.E., Madoffe, S.S., Munishi, P.K.T., Nashanda, E. Kerry Turner, R., Balmford, A., 2012. Estimating management costs of protected areas: a novel approach from the Eastern Arc Mountains, Tanzania. Biol. Conserv. 150, 5-14.

Hansen, A.J., DeFries, R., 2007. Ecological mechanisms linking protected areas to surrounding lands. Ecol. Appl. 17, 974-988.

Hougner, C., Colding, J., Söderqvist, T., 2006. Economic valuation of a seed dispersal service in the Stockholm National Urban Park, Sweden. Ecol. Econ. 59, 364-374.

Jacobsen, J.B., Thorsen, B.J., 2010. Preferences for site and environmental functions when selecting forthcoming national parks. Ecol. Econ. 69, 1532-1544. 
Jones, N., Clark, J., Panteli, M., Proikaki, M., Dimitrakopoulos, P., 2012. Local social capital and the acceptance of Protected Area policies: an empirical study of two Ramsar river delta ecosystems in northern Greece. J. Environ. Manag. 96, 55-63.

Juutinen, A., Mitani, Y., Mäntymaa, E., Shoji, Y., Siikamäki, P., Svento, R., 2011. Combining ecological and recreational aspects in national park management: a choice experiment application. Ecol. Econ. 70, 1231-1239.

Kari, S., Korhonen-Kurki, K., 2013. Framing local outcomes of biodiversity conservation through ecosystem services: a case study from Ranomafana, Madagascar. Ecosyst. Serv. 3, e32-e39.

Kovacs, K.F., 2012. Integrating property value and local recreation models to value ecosystem services from regional parks. Landsc. Urban Plan. 108, 79-90.

Kümmerling, M., Müller, N., 2012. The relationship between landscape design style and the conservation value of parks: a case study of a historical park in Weimar, Germany. Landsc. Urban Plan. 107, 111-117.

Liira, J., Lõhmus, K., Tuisk, E., 2012. Old manor parks as potential habitats for forest flora in agricultural landscapes of Estonia. Biol. Conserv. 146, 144-154.

Mackenzie, C.A., 2012. Accruing benefit or loss from a protected area: location matters. Ecol. Econ. 76, 119-129.

Martínez-Harms, M.J., Gajardo, R., 2008. Ecosystem value in the Western Patagonia protected areas. J. Nat. Conserv. 16, 72-87.

Martín-López, B., García-Llorente, M., Palomo, I., Montes, C., 2011. The conservation against development paradigm in protected areas: valuation of ecosystem services in the Doñana social-ecological system (southwestern Spain). Ecol. Econ. 70, 1481-1491.

Martín-López, B., Gómez-Baggethun, E., Lomas, P.L., Montes, C., 2009. Effects of spatial and temporal scales on cultural services valuation. J. Environ. Manag. 90, 1050-1059.

Mcdonald, R.I., Forman, R.T.T., Kareiva, P., Neugarten, R., Salzer, D., Fisher, J., 2009. Urban effects, distance, and protected areas in an urbanizing world. Landsc. Urban Plan. 93, 63-75.

Padilla, F.M., Vidal, B., Sánchez, J., Pugnaire, F.I., 2010. Land-use changes and carbon sequestration through the twentieth century in a Mediterranean mountain ecosystem: implications for land management. J. Environ. Manag. 91, 2688-2695.

Palomo, I., Martín-López, B., Potschin, M., Haines-Young, R., Montes, C., 2013. National Parks, buffer zones and surrounding lands: mapping ecosystem service flows. Ecosyst. Serv. 4, 104-116.

Payés, A.C.L.M., Pavão, T., Santos, R.F., 2013. The conservation success over time: evaluating the land use and cover change in a protected area under a long recategorization process. Land Use Policy 30, 177-185.

Petrosillo, I., Semeraro, T., Zurlini, G., 2010. Detecting the 'conservation effect' on the maintenance of natural capital flow in different natural parks. Ecol. Econ. 69, 1115-1123.

Petrosillo, I., Zaccarelli, N., Semeraro, T., Zurlini, G., 2009. The effectiveness of different conservation policies on the security of natural capital. Landsc. Urban Plan. 89, 49-56.
Petrosillo, I., Zurlini, G., Corlianò, M.E., Zaccarelli, N., Dadamo, M., 2007. Tourist perception of recreational environment and management in a marine protected area. Landsc. Urban Plan. 79, 29-37.

Pettorelli, N., Chauvenet, A.L.M., Duffy, J.P., Cornforth, W.A., Meillere, A., Baillie, J.E. M., 2012. Tracking the effect of climate change on ecosystem functioning using protected areas: Africa as a case study. Ecol. Indic. 20, 269-276.

Pietrzyk-Kaszyńska, A., Cent, J., Grodzińska-Jurczak, M., Szymańska, M., 2012. Factors influencing perception of protected areas-the case of Natura 2000 in Polish Carpathian communities. J. Nat. Conserv. 20, 284-292.

Rayfield, B., James, P., Fall, A., Fortin, M.J., 2008. Comparing static versus dynamic protected areas in the Quebec boreal forest. Biol. Conserv. 141, 438-449.

Rescia, A.J., Willaarts, B.A., Schmitz, M.F., Aguilera, P.A., 2010. Changes in land uses and management in two Nature Reserves in Spain: evaluating the socialecological resilience of cultural landscapes. Landsc. Urban Plan. 98, 26-35.

Ring, I., 2008. Integrating local ecological services into intergovernmental fiscal transfers: the case of the ecological ICMS in Brazil. Land Use Policy 25, 485-497.

Rodríguez-Rodríguez, D., Martínez-Vega, J., 2012. Proposal of a system for the integrated and comparative assessment of protected areas. Ecol. Indic. 23, $566-572$.

Rogers, H.M., Glew, L., Honzák, M., Hudson, M.D., 2010. Prioritizing key biodiversity areas in Madagascar by including data on human pressure and ecosystem services. Landsc. Urban Plan. 96, 48-56.

Roux, D.J., Nel, J.L., Ashton, P.J., Deacon, A.R., de Moor, F.C., Hardwick, D., Hill, L., Kleynhans, C.J., Maree, G.A., Moolman, J., 2008. Designing protected areas to conserve riverine biodiversity: lessons from a hypothetical redesign of the Kruger National Park. Biol. Conserv. 141, 100-117.

Shafer, C.L., 2004. A geography of hope: pursuing the voluntary preservation of America's natural heritage. Landsc. Urban Plan. 66, 127-171.

Sims, K.R.E., 2010. Conservation and development: evidence from Thai protected areas. J. Environ. Econ. Manag. 60, 94-114.

Strickland-Munro, J.K., Allison, H.E., Moore, S.A., 2010. Using resilience concepts to investigate the impacts of protected area tourism on communities. Ann. Tour. Res. 37, 499-519.

van Riper, C.J., Kyle, G.T., Sutton, S.G., Barnes, M., Sherrouse, B.C., 2012. Mapping outdoor recreationists' perceived social values for ecosystem services at Hinchinbrook Island National Park, Australia. Appl. Geogr. 35, 164-173.

Velarde, S.J., Malhi, Y., Moran, D., Wright, J., Hussain, S., 2005. Valuing the impacts of climate change on protected areas in Africa. Ecol. Econ. 53, 21-33.

Vodouhê, F.G., Coulibaly, O., Adégbidi, A., Sinsin, B., 2010. Community perception of biodiversity conservation within protected areas in Benin. For. Policy Econ. 12, 505-512.

Wade, A.A., Theobald, D.M., Laituri, M.J., 2011. A multi-scale assessment of local and contextual threats to existing and potential US protected areas. Landsc. Urban Plan. 101, 215-227. 